Иманшапиева М.M. Региональные особенности применения упрощенной системы налогообложения и пути её совершенствования (по материалам Республики Дагестан)

УДК 336.221

DOI: $10.21779 / 2500-1930-2016-31-3-30-35$

\title{
М.М. Иманшапиева
}

\section{Региональные особенности применения упрощенной системы налогообложения и пути её совершенствования (по материалам Республики Дагестан)}

Дагестанский государственный аграрный университетимени М.М. Джамбулатова; Россия, 367032, г. Махачкала, ул. М. Гаджиева, д.180;Mazika21@rambler.ru

В России с развитием малого бизнеса связывают большие надежды в решении современных проблем российской экономики: развитие производства и торговли, обеспечение занятости населения, увеличение бюджетных доходов. В статье с учетом особенностей субъектов малого предпринимательства аргументирована необходимость усиления роли налоговой политики в регулировании их деятельности. Проведен анализ результатов выездных налоговых проверок по группам взаимосвязанных лиц за последние три года на рабочих совещаниях Управлений ФНС России с представителями налоговых инспекций. Предложены рекомендации по совершенствованию механизма взимания и уплаты налогов при применении упрощенной системы налогообложения субъектов малого предпринимательства и повышению качества проведения налогового контроля. Помимо этого автором выявлены дополнительные меры, позволяющие предотвратить нарушение налогового законодательства субъектами малого бизнеса.

Ключевые слова: субъекты малого предпринимательства, упрощенная система налогообложения, развитие, налоги, режимы, ставки, контроль, проверки.

Одним из направлений обеспечения устойчивости экономического роста РФ, многократно подтвержденным мировой практикой, является развитие малого бизнеса наиболее мобильного, рискованного и конкурентоспособного сегмента экономики любой страны. Почти треть населения России так или иначе связана с малым бизнесом.

Сравнительные исследования подтверждают, что роль и значение малого бизнеса в экономике России в силу исторических, экономических, политических и социальных причин значительно ниже, чем в развитых странах. Так, вклад предприятий малого бизнеса в ВВП России составил в 2008 г.12,6 \% , в 2009 г. - $17 \%$, в 2010 г. - $21 \%$, в 2011 г. $-19 \%$, в 2012 г. - $18 \%$, в 2013 г. $-20 \%$, в 2014 г. $-18 \%$, в 2015 г. - $19 \%$ [2,c. 13], в то время как в ведущих странах мира - от 51до $61 \%$.

Сложившаяся в российской экономике ситуация все более настойчиво сигнализирует о необходимости принятия срочных мер по увеличению доходной базы бюджетной системы страны, и в первую очередь региональных бюджетов [9,c. 3].

Отметим, что министр финансов Антон Силуановв своем выступлении в рамках прошедшего в 2014 г. в Санкт-Петербурге международного экономического форума заявил: «Нам нужны ресурсы для инфраструктурных решений, роста малого и среднего бизнеса. Сбор доходов должен обеспечиваться не путем увеличения налоговой нагрузки, а снижением теневого сектора, деофшоризацией, созданием благоприятных условий в России. Поэтому, принимая во внимание заявления профильных чиновников, экспертное сообщество ожидает, что основное внимание будет уделено ужесточению методов налогового администрирования и введению дополнительных мер контроля за ведением бизнеса» [2,с. 16].

Специальные налоговые режимы применяются с целью создания более благоприятных экономических условий функционирования организаций и индивидуальных предпринимателей, упрощения системы учета и отчетности. Как известно, применение 
Иманшапиева M.M. Региональные особенности применения упрощенной системы налогообложения и пути её совершенствования (по материалам Республики Дагестан)

специальных налоговых режимов освобождает налогоплательщиков от уплаты ряда федеральных, региональных и местных налогов и сборов.

Исходя из темы нашего исследования, для комплексного системного решения задач по совершенствованию упрощенной системы налогообложения, применяемой субъектами малого предпринимательства, проанализируем налоговые поступления УСН в Республике Дагестан за последние годы.

Таблица 1

Динамика и структура налоговых поступленийпо упрощенной системе налогообложения в РД за 2011-2015 гг. (млн руб., \%)[12]

\begin{tabular}{|l|l|l|l|l|l|l|l|}
\hline & 2011 & 2012 & 2013 & 2014 & 2015 & $\begin{array}{l}\text { Откл. } \\
2013- \\
2014, \text { в \% }\end{array}$ & $\begin{array}{l}\text { Откл. } \\
2014- \\
2015, \\
\text { в \% }\end{array}$ \\
\hline $\begin{array}{l}\text { Сумма налога, подлежа- } \\
\text { щая уплате по спец. нало- } \\
\text { говым режимам, } \\
\text { из нихпо: }\end{array}$ & 679,2 & 776,3 & 791,8 & 852,8 & 1153,8 & 7,7 & 35,3 \\
\hline УСН, в т.ч. по объекту: & 380,5 & 421,7 & 543,2 & 519,8 & 609,8 & $-4,3$ & 17,3 \\
\hline - «доходы» & 256,0 & 282,5 & 349,7 & 308,4 & 339,6 & $-11,8$ & 10,1 \\
\hline - «доходы минус расходы» & 124,5 & 139,2 & 184,4 & 211,4 & 270,2 & 14,6 & 27,8 \\
\hline Сумма минимального налога & 42,1 & 49,5 & 55,4 & 64,3 & 52,8 & 16,1 & $-17,9$ \\
\hline
\end{tabular}

* Составлена по отчетным данным УФНСРФ поРеспублике Дагестан за 2011-2015 ГГ.

По отчетным данным УФНС России по РД сумма налогов, поступивших от деятельности субъектов малого и среднего предпринимательства в консолидированный бюджет Республики Дагестан, составила в 2010 году - 2 505,3 млн руб., в 2011 г. 2008,3 млн руб.ив 2012 г. - 2 194,7 млн руб., в 2013 г. - 2287,0 млн руб., в 2014 г. 2057, в 2015 г. -2240.

Таким образом, в 2015 году наблюдается снижение налоговых поступлений от деятельности субъектов малого предпринимательства на 10 \% относительно 2010 года.

В 2015 году число малых предприятий составило 6991 ед. (включая микропредприятия), что на 9 \% меньше, чем в 2014 году, а количество субъектов малого и среднего предпринимательства уменьшилось за год на $6 \%$ и составило 50546 ед. Согласно отчетным даннымДагестанстата, всего на 1 января 2016 года в базе данных единого Статрегистра имеются сведения о 42175 действующих индивидуальных предпринимателях и8 152 главах КФХ, при этом основная часть субъектов малого бизнеса республики сконцентрирована в городах.

При этом по УСН за 2015 год налоговыми органами было мобилизовано 609,8 млн руб., что на 35,3 \% больше, чем в 2014 году, а количество налогоплательщиков, представивших налоговые декларации по УСН за аналогичный период, увеличилось на 6,3\% (таблицы1,2).

Что свидетельствует об увеличении объемов производства, оборота розничной и оптовой торговли предпринимателей, применяющих упрощенную систему налогообложения.Кроме того, рост налогоплательщиков по УСН объясняется переходом части налогоплательщиков, применяющих ЕНВД, на упрощенную систему налогообложения в связи с ростом коэффициента дефлятора К1. 
Иманшапиева М.М. Региональные особенности применения упрощенной системы налогообложения и пути её совершенствования (по материалам Республики Дагестан)

Следует отметить, что в Республике Дагестаннаиболее распространёнными видами деятельности, подпадающими под данный вид налогообложения, являются строительство и реализация ГСМ, большая часть доходов которых находится«в тени».

Особенности налогового администрирования индивидуальныхпредпринимателей и малых предприятий в сфере розничной торговли, оказания бытовых, автотранспортных услуг не позволяютналоговым органамэффективно контролировать правильность исчисления налоговой базы. Поскольку не были ликвидированы условия дляухода указанных налогоплательщиков от уплаты налогов и развития «теневого» бизнеса.

Таблица 2

Характеристиканалогоплательщиков упрощенной системы налогообложения в РД за 2011-2015 гг. (ед. чел.)[12]

\begin{tabular}{|c|c|c|c|c|c|c|c|}
\hline & 2011 & 2012 & 2013 & 2014 & 2015 & $\begin{array}{l}\text { Откл. } \\
2013- \\
2014, \\
\text { в \% }\end{array}$ & $\begin{array}{l}\text { Откл. } \\
2014- \\
2015, \\
\text { в \% }\end{array}$ \\
\hline $\begin{array}{l}\text { Количество налогопла- } \\
\text { тельщиков, предста- } \\
\text { вивших } \\
\text { декларации поговые } \\
\text { (ед./чел.), всего: }\end{array}$ & 9349 & 8986 & 8982 & 9888 & 10512 & 10,1 & 6,3 \\
\hline $\begin{array}{l}\text { по объекту нало- } \\
\text { гообложения - «дохо- } \\
\text { ды» }\end{array}$ & 5406 & 4854 & 4668 & 5057 & 5239 & 8,3 & 3,6 \\
\hline $\begin{array}{l}\text { по объекту нало- } \\
\text { гообложения - «дохо- } \\
\text { ды, уменьшенные на } \\
\text { величину расходов» }\end{array}$ & 3943 & 4132 & 4314 & 4831 & 5273 & 12,0 & 9,1 \\
\hline
\end{tabular}

*Составлена по отчетным данным УФНСРФ поРеспублике Дагестан за 2011-2015 ГГ.

Таким образом, налоговые поступления от УСН по-прежнему составляют малую долю в бюджете республики (лишь 2,1 \% от суммы налоговых платежейконсолидированного бюджета РД за 2015 г.), что является следствием, в том числе и недостаточно эффективного проведения мероприятий налогового администрирования.

Для оценки результатов осуществления налогового администрирования налоговыми органами в отношении субъектов малого предпринимательствана региональном уровне рассмотрим контрольную деятельность налоговых органов Республики Дагестан по упрощенной системе налогообложения.

Эффективность мероприятий налогового контроля зависит главным образом от эффективности проведения выездных налоговых проверок.Налоговыми органами Республики Дагестан по УСН за 2015 год проведено 76 выездных налоговых проверок и 11503 камеральные проверки, по результатам которых доначислено платежей на общую сумму 38953 тыс. рублей, что на 2877 тыс. рублей, или 7,9 \%, больше, чем по итогам 2014 года (таблица 4).

Но отметим, что эффективность выездных налоговых проверок снизилась.Так, если в 2015 году по упрощенной системе количество выездных проверок уменьшилось на 
Иманшапиева M.M. Региональные особенности применения упрощенной системы налогообложения и пути её совершенствования (по материалам Республики Дагестан)

22,5 \% относительно 2014 года, то суммы доначислений по данному налогу по результатам выездных проверок уменьшились за аналогичный периодна 6 \%.

Таблица 3

Динамика налоговых проверок по упрощенной системе налогообложения по результатам контрольной деятельностипо РД за 2013-2015 гг. (ед)[12]

\begin{tabular}{|l|l|l|l|l|l|l|l|l|l|l|}
\hline & \multicolumn{2}{|l|}{$\begin{array}{l}\text { Количество про- } \\
\text { веденных ВН* }\end{array}$} & \multicolumn{2}{l|}{$\begin{array}{l}\text { Количество проведен- } \\
\text { ных КП** }\end{array}$} & \multicolumn{2}{l|}{ Откл.по ВП } & \multicolumn{2}{l|}{ Откл.по КП } \\
\cline { 2 - 10 } & 2013 & 2014 & 2015 & 2013 & 2014 & 2015 & $\begin{array}{l}2013- \\
2014\end{array}$ & $\begin{array}{l}2014- \\
2015\end{array}$ & $\begin{array}{l}2013- \\
2014\end{array}$ & $\begin{array}{l}2014 \\
- \\
2015\end{array}$ \\
\hline $\begin{array}{l}\text { Всего } \\
\text { по } \\
\text { УСН и } \\
\text { ЕНВД }\end{array}$ & 172 & 149 & 113 & 67469 & 65999 & 65597 & -23 & -36 & -1470 & -402 \\
\hline УСН & 138 & 98 & 76 & 10697 & 12223 & 11503 & -40 & -22 & 1526 & -720 \\
\hline
\end{tabular}

Составлено по даннымУФНС РФ по РД за 2013-2015гг.

*ВП - выездные проверки;**КП - камеральные проверки.

Отметим, чтов рамках УСН в 2015 году по результатам камеральных проверок было доначислено 14713 тыс. рублей, а по результатам выездных проверок - 24240 тыс. рублей. Таким образом, в сумме доначислений по УСН преобладают доначисления от выездных налоговых проверок - (62,2 \% (от камеральных - 37,8 \%) (Таблица 4).

Одновременно в абсолютном выражении в 2015 году по сравнению с2014 годом сумма доначислений от выездных налоговых проверок в рамках УСН уменьшилась на 1494 тыс.рублей, или на 6 \%, что свидетельствует о снижении качества проведения выездных проверок.

Таблица 4

Динамика налоговых поступлений в результате выездных налоговых проверокв рамках применения УСН за 2013-2015 годы, тыс. рублей[12]

\begin{tabular}{|c|c|c|c|c|c|c|c|}
\hline \multirow{3}{*}{$\begin{array}{l}\text { Суммы дона- } \\
\text { числений }\end{array}$} & \multicolumn{7}{|l|}{ ВП } \\
\hline & \multirow{2}{*}{2013} & \multirow{2}{*}{2014} & \multirow{2}{*}{2015} & \multicolumn{2}{|c|}{ откл. 2013-2014 } & \multicolumn{2}{|c|}{ откл. 2014-2015 } \\
\hline & & & & сумма & $8 \%$ & сумма & в $\%$ \\
\hline $\begin{array}{l}\text { Всего по УСН } \\
\text { и ЕНВД }\end{array}$ & 22412 & 25493 & 24240 & 3081 & 13,7 & -1253 & $-4,9$ \\
\hline УCH & 21944 & 25037 & 23543 & 3093 & 14,1 & -1494 & $-6,0$ \\
\hline
\end{tabular}

Составлено по даннымУФНС РФ по РД за 2013-2015 гг.

*ВП - выездные проверки;**КП - камеральные проверки.

Таким образом, в целях усиления контрольной деятельности налоговых органов в рамках специальных режимов необходимо прежде всего усилить аналитическую со- 
Иманшапиева М.M. Региональные особенности применения упрощенной системы налогообложения и пути её совершенствования (по материалам Республики Дагестан)

ставляющую оценки деятельности субъектов малого бизнеса, а также шире использовать информацию от третьих лиц, повышать качество налогового администрирования в части планирования проверок и прогнозирования налоговых поступлений.

В свою очередь эффективность налогового контроля во многом зависит от правильного выбора форм, методов и видов налогового контроля. Необходимо усилить работу по межведомственному взаимодействию фискальных и правоохранительных органов государственной власти. Важным направлением должна стать работа по обеспечению контроля за деятельностью недобросовестных налогоплательщиков, выплачивающих заработную плату в конвертах, имеющих просроченную задолженность по налогам или отражающих в налоговой отчетности заниженные сведения о своей деятельности.

Автором предлагается проанализировать результаты выездных налоговых проверок по группам взаимосвязанных лиц за последние три года на рабочих совещаниях Управлений ФНС России с представителями налоговых инспекций, проводивших выездные налоговые проверки, с целью рассмотрения вопроса о целесообразности проведения повторных выездных налоговых проверок, с привлечением правоохранительных органов.

Указанные выше рекомендации позволят оказать положительное влияние на отбор налогоплательщиков, организацию планирования выездных налоговых проверок и повысить эффективность их проведения.

Сложившаяся ситуация требуетповышения эффективности контрольной работы налоговых органов, совершенствования всех используемых приемов и методов контрольной работы.

Необходимо в условиях проводимых трансформационных преобразований иреального улучшения положения в деле воспитания нового типа налогоплательщика, уважающего налоговое законодательство и по собственной воле уплачивающего налоги, в налоговомзаконодательствезакрепить принцип «виновности налогоплательщика», который принят в большинстве развитых государств.

В целях усиления контрольной деятельности налоговых органов в рамках специальных режимов налогообложения необходимо прежде всего усилить аналитическую составляющую оценки деятельности субъектов малого бизнеса, а также шире использовать информацию от третьих лиц, повышать качество налогового администрирования в части планирования проверок и прогнозирования налоговых поступлений.

\section{Литература}

1. Налоговый кодекс Российской Федерации. - М.: Омега-Л, 2014.

2. Бизнес-Информ. Информационный бюллетень Санкт-Петербургской Торговопромышленной палаты. Апрель - июнь 2014. - № 2 (45).

3. Екимова K.В., Гришанов А.В. Налоговая конкуренция на уровне муниципалитетов //Налоговая политика и практика.2014 сентябрь. -№ 9 (141). -C.28.

4. Емельянов И.А. Малое предпринимательство: организация, экономика, управление / под ред. А.Д. Шеремета. - М.: ИНФРА-М, 2010. - С. 176.

5. Иманшапиева М.M. Легализация теневого сектора экономики как фактор повышения экономической активности регионов (по материалам Республики Дагестан) // Финансы и кредит. Август 2013. - № 31(559). - С. 61-68.

6. Иманшапиева М.M., Мусаева Х.М. Анализ и оценка практики налогообложения субъектов малого предпринимательства (по материалам Республики Дагестан) // Налоги и налогообложение. - 2012. - № 4. - С. 35-43. 
Иманшапиева М.M. Региональные особенности применения упрощенной системы налогообложения и пути её совершенствования (по материалам Республики Дагестан)

7. Налоговая политика России - непростые задачи и сложные вызовы //Финансы. - 2014. - № 11. - С.51.

8. Налоги и налоговая система РФ: учеб.пособие / под ред. Алиева Б.Х., Мусаевой Х.М. - М.: ЮНИТИ-ДАНА, 2014. - С. 439.

9. Пансков В.Г. О пополнении доходной части бюджетной системы // Финансы. - 2014. -№ 8. - C.3-8.

10. Перонко И. А., Красницкий В.А. Налоговое администрирование // Налоговый вестник. - 2014. - № 37. - С.24.

11. Официальные данные сайта Федеральной службы государственной статистики (Росстат): www.gks.ru. URL:http:/www.gks.ru/wps/wcm/(дата обращения 12.06.2014).

12. Официальныеданные сайта ФНС РФ: www.nalog.ru. URL: http://www.nalog.ru/nal_statistik/statistic/budjet/(дата обращения 12.08.2014).

Поступила в редакцию 17 сентября 2016 г.

UDC 336.221

DOI: $10.21779 / 2500-1930-2016-31-3-30-35$

\section{Simplified taxation system:regional specific features and ways to develop (a case study of the Republic of Dagestan)}

\section{M.M.Imanshapiyeva}

Dagestan State agricultural university of M. M. Dzhambulatov; Russia, 367001, Makhachkala, M. Gadzhiyevst.,180;mazika21@rambler.ru

Great expectations connected with the topical problems of Russian economy in small business to be solved are: production and trade development; employment policy; growth of budget incomes. Taking into account the features characteristic of small business the authors postulate the idea of enhancing tax policy and regulating their activity. The results of field tax examinations in the groups of interrelated subjects held at working meetings of the Department of the Federal Tax Service with the representatives of tax inspections during the last 3 years are summarized. The author gives some recommendations to enhance the mechanism of collecting and paying taxes and to simplify the system of taxation for small business to improve quality of tax control. Besides, the author reveals additional measures to prevent violation of tax legislation by the subjects of small business.

Keywords: small business entities, simplified system of the taxation, development, taxes, modes, rates, control, checks.

Received 17September, 2016 